\title{
SLACK IN CONSTRUCTION - PART 2: PRACTICAL APPLICATIONS
}

\author{
Tarcisio Abreu Saurin', Daniela Dietz Viana ${ }^{2}$, Carlos Torres Formoso ${ }^{3}$, \\ Iris D. Tommelein ${ }^{4}$, Lauri Koskela ${ }^{5}$, Marcus Fireman ${ }^{6}$, Karina Barth ${ }^{7}$, \\ Fernanda Bataglin ${ }^{8}$, Rafael Coelho ${ }^{9}$, Vishesh Singh ${ }^{10}$, Carolina Zani ${ }^{11}$, \\ Natália Ransolin ${ }^{12}$, and Claudia Guerra Disconzi ${ }^{13}$
}

\begin{abstract}
Construction projects are exposed to a wide diversity of variabilities, which suggests the existence of a correspondent wide diversity of variability coping mechanisms, whether they are designed or not. This wide diversity is not properly accounted for by the concept of buffer, as it neglects the social and informal dimensions of coping with variability. The use of the concept of slack is proposed as an alternative. A companion IGLC 29 paper defines slack and discusses its relationships with proxy concepts such as flexibility and resilience. This paper presents nine practical examples of slack in managerial processes and topics that are of interest for the lean construction community. These examples suggest that, while slack has been concealed by the lack of theorization and consistent terminology, it is ubiquitous in lean construction. Opportunities for future studies are outlined.
\end{abstract}

1 Associate Professor, Industrial Engineering and Transportation Department, Federal University of Rio Grande do Sul, Brazil, saurin@ufrgs.br, orcid.org/0000-0003-2929-5888

2 Adjunct Professor, Interdisciplinary Department, NORIE, UFRGS, dietz.viana@ufrgs.br, orcid.org/0000-0001-8958-4708

3 Professor, Building Innovation Research Unit (NORIE), Universidade Federal do Rio Grande do Sul (UFRGS). Porto Alegre, RS, Brazil, formoso@ufrgs.br, orcid.org/0000-0002-4772-3746

4 Professor, Civil and Envir. Engrg. Dept., Director, Project Production Systems Laboratory (P2SL), University of California, Berkeley, CA, tommelein@berkeley.edu, orcid.org/0000-0002-9941-6596

5 Professor of Construction and Project Management, School of Art, Design and Architecture. University of Huddersfield, Queensgate, Huddersfield, UK, 1.koskela@ hud.ac.uk, orcid.org/0000-0003-4449$\underline{2281}$

6 PhD Student, Postgraduate Program in Civil Eng.: Construction and Infrastructure, UFRGS, Porto Alegre 90035-190, Brazil, marcus@ climbgroup.com.br, orcid.org/0000-0001-5843-4715

7 PhD Candidate, NORIE, Federal University of Rio Grande do Sul, Brazil, Consultant and Managing Partner at LD Consulting, kbertotto@gmail.com, orcid.org/0000-0001-9612-6246

8 PhD Candidate, Postgraduate Program in Civil Eng.: Construction and Infrastructure, UFRGS, Porto Alegre, Brazil, fernanda.saidelles@ gmail.com, orcid.org/0000-0001-8859-1201

$9 \quad$ PhD Student, Civil and Envir. Eng. Dept. and Project Production Systems Laboratory (P2SL), Univ. of California, Berkeley, CA, USA, rvcoelho@ berkeley.edu, orcid.org/0000-0003-3298-3622

10 PhD Student, Civil and Envir. Eng. Dept. and Project Production Systems Laboratory (P2SL), Univ. of California, Berkeley, CA, USA, visheshvs@ berkeley.edu, orcid.org/0000-0002-6999-9727

11 MSc Student, Postgraduate Program in Production Eng. UFRGS, Porto Alegre, Brazil, zani.carol@gmail.com, orcid.org/0000-0002-2649-2432

12 PhD Candidate, Postgraduate Program in Civil Eng.: Construction and Infrastructure, UFRGS, Porto Alegre, Brazil, natalia.ransolin@ufrgs.br, orcid.org/0000-0002-7128-8000

13 PhD Candidate, Postgraduate Program in Industrial Eng., UFRGS, Porto Alegre 90035-190, Brazil, claudiaguerraep@gmail.com, orcid.org/0000-0002-4224-5167 


\section{KEYWORDS}

Slack, complexity, concept map.

\section{INTRODUCTION}

Construction projects are subject to a wide range of variabilities, which reflects their complex nature and interactions with the external environment. According to Koskela (2000) there are eight groups of preconditions for the start of construction tasks: design, components and materials, workers, equipment, space, connecting works, external conditions, and temporary facilities. These preconditions can vary across a number of dimensions such as time (e.g., when they are made available too late or too early) and precision (e.g., non-conformance to technical specifications) (Hollangel, 2012).

As a result, variability coping mechanisms (either designed or not) are likely to cover a wide range of possibilities. In fact, a match between variabilities and their countermeasures is necessary in complex systems as stated by the law of requisite variety (Ashby, 1991). This law states that a system can be stable only if the number of possible states of its control mechanisms is equal to or greater than the number of possible states of the system. Thus, there should be a minimum variety of (e.g., skills, materials and tools) to match the variety from the environment (e.g., demand volatility, resources availability).

However, variability coping mechanisms in construction and in other sectors are usually approached in the production management literature from a limited perspective, as formed by three types of buffers, namely capacity, inventories, and time (Spearman and Hopp, 2020). Furthermore, the literature on buffers neglects both the social and the informal dimensions of variability coping, offering an overly technical and mechanistic perspective. For these reasons, Formoso et al. (2021) (a companion publication to this paper) propose the use of a new concept and theorization capable of: $(i)$ integrating a wide range of variability coping mechanisms that account for both formal and informal approaches, across all relevant processes at the micro, meso, and macro levels of project production systems; and (ii) inspiring a revision of lean construction practices so as to check (and increase) the extent to which they are fit to the growing levels of complexity and risk that characterize construction projects. Formoso et al. (2021) argue that the concept of slack can fulfil this knowledge gap.

Slack is defined by Bourgeois (1981) as "a cushion of actual or potential resources which allows an organization to adapt successfully to internal pressures for adjustment or to external pressures for change in policy". Formoso et al. (2021) explored how slack is related to other proxy terms (e.g., flexibility, resilience) and presented a concept map that schematically illustrates their relationships. The present paper further illuminates the concept of slack in construction by presenting a number of practical examples derived from both the literature and the authors' experience as lean construction scholars and practitioners. These examples encompass managerial processes and topics that are of interest to the lean construction community such as production planning and control, lean and BIM, safety management, supply chain management, and off-site construction. Based on this, we intend to reinforce the theoretical relevance and practical utility of the concept of slack to lean construction. In fact, while slack seems to be ubiquitous in lean construction, it has been concealed by the lack of theorization and consistent terminology. Opportunities for further studies are discussed. 


\section{EXAMPLES OF SLACK IN PRODUCTION MANAGEMENT}

The nine examples of slack presented next stem from two sources: $(i)$ research projects underway led by some of the 13 authors of this paper on the topics of lean construction, resilience engineering, and production planning and control - the authors have had access to diverse empirical settings such as large construction projects where lean construction principles have been applied (e.g., Fireman and Saurin, 2020) and the built environment of healthcare facilities (e.g., Ransolin et al., 2020); and (ii) reinterpretation of known management practices (e.g., BIM, escape emergency routes in buildings) from the viewpoint of slack. These examples are classified according to: (i) the slack strategies adopted (Table 1); (ii) the slack resources involved; (iii) the rationale for using slack (i.e., why is slack needed?); and (iv) the unintended consequences of using slack.

The examples are presented in Figures 1 through 9.

Table 1: Slack strategies (adapted from Formoso et al. 2021)

\begin{tabular}{cc}
\hline Slack strategies & Definition \\
\hline Flexibility & $\begin{array}{c}\text { The ability of an organization to deploy and redeploy its resources } \\
\text { effectively in response to changing environmental and internal } \\
\text { conditions (Gerwin, 1993). }\end{array}$ \\
Redundancy & $\begin{array}{c}\text { A condition where some types of resources are provided in } \\
\text { addition to the minimum necessary to perform a specific function } \\
\text { (Nonaka, 1990), or when more than one resource performs a } \\
\text { required function (Azadeh et al., 2016). }\end{array}$ \\
Margins of manoeuvre & $\begin{array}{r}\text { It addresses the creation or maintenance of margins and } \\
\text { additional resources that allow the system to continue to function } \\
\text { despite unexpected demands (Saurin and Werle, 2017) }\end{array}$ \\
\hline
\end{tabular}

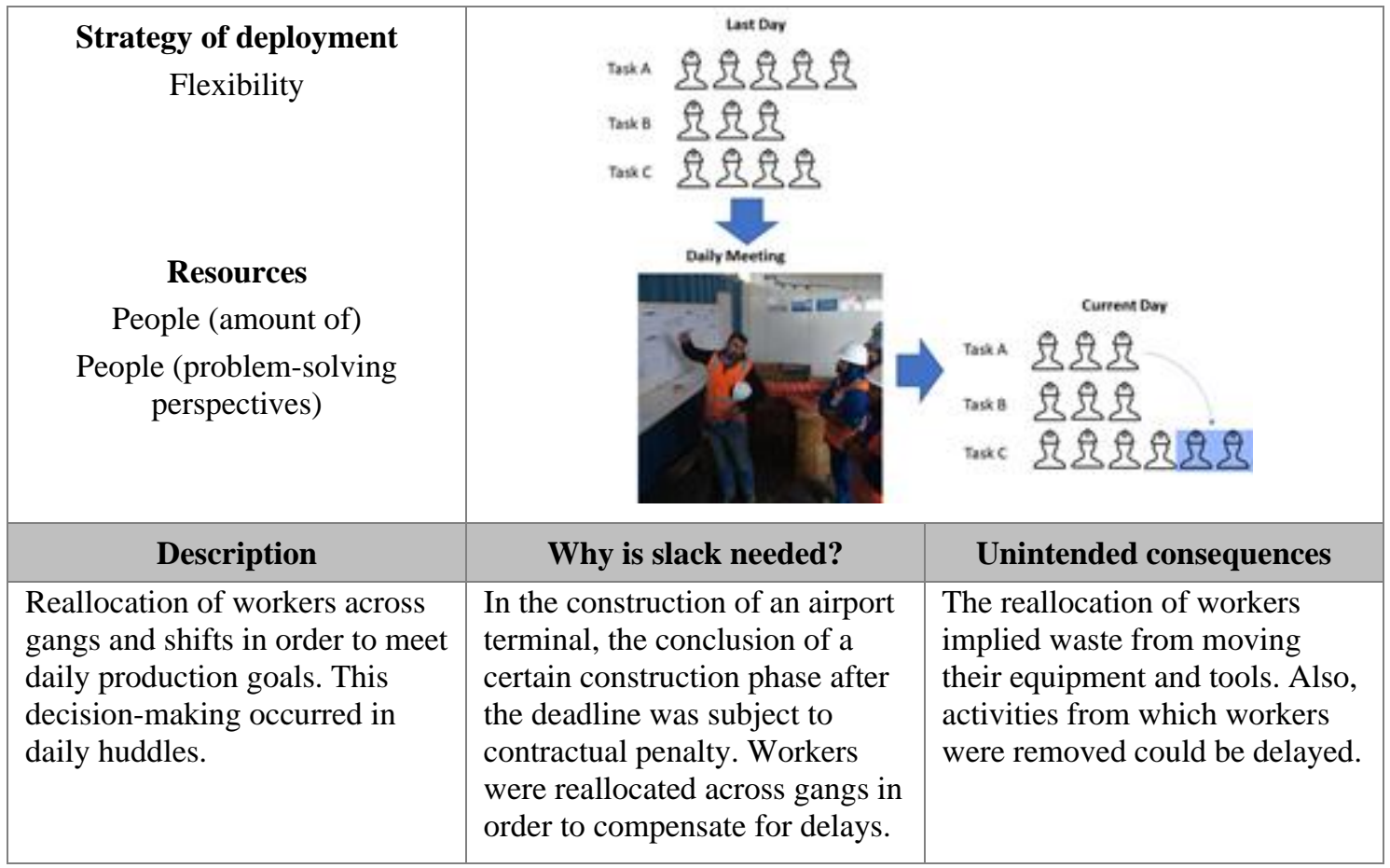

Figure 1: Example 1 - slack in production planning and control (based on Fireman and Saurin, 2020) 


\begin{tabular}{|c|c|c|}
\hline $\begin{array}{c}\text { Strategy of deployment } \\
\text { Redundancy }\end{array}$ \\
$\begin{array}{c}\text { Resource } \\
\text { Design }\end{array}$ \\
\hline \multicolumn{1}{c|}{$\begin{array}{c}\text { Description } \\
\text { Why is slack needed? }\end{array}$} \\
\hline $\begin{array}{l}\text { Alternative designs, considering } \\
\text { different types of soil, for the } \\
\text { foundations of electricity } \\
\text { transmission towers. }\end{array}$ & $\begin{array}{l}\text { Due to the heterogeneity of the } \\
\text { soil and the limited soil surveys, } \\
\text { the standard design of the } \\
\text { foundations may not be } \\
\text { applicable. }\end{array}$ & $\begin{array}{l}\text { Extra short-term costs for } \\
\text { producing alternative designs. } \\
\text { These costs may pay back in the } \\
\text { long-term as the same design is } \\
\text { reused in other projects. }\end{array}$ \\
\hline
\end{tabular}

Figure 2: Example 2 - set-based product design as slack

\begin{tabular}{|c|c|c|}
\hline $\begin{array}{c}\text { Strategy of deployment } \\
\text { Redundancy }\end{array}$ \\
$\begin{array}{c}\text { Resource } \\
\text { People }\end{array}$ & Why is slack needed? & \multicolumn{1}{c|}{ Unintended consequences } \\
\hline $\begin{array}{l}\text { Description } \\
\text { Multi-skilled employee who can } \\
\text { operate a crane in case the } \\
\text { regular operator is absent for } \\
\text { any reason }\end{array}$ & $\begin{array}{l}\text { Hiring and training a new crane } \\
\text { operator takes time. }\end{array}$ & $\begin{array}{l}\text { Wages of multi-skilled } \\
\text { employees are higher than those } \\
\text { of regular employees. The } \\
\text { activity from which the multi- } \\
\text { skilled operator was removed is } \\
\text { subject to delays. }\end{array}$ \\
\hline
\end{tabular}

Figure 3: Example 3-multi-skilled workers as slack 
Tarcisio Abreu Saurin, Daniela Dietz Viana, Carlos Torres Formoso, Iris D. Tommelein, Lauri Koskela, Marcus Fireman, Karina Barth, Fernanda Bataglin, Rafael Coelho, Vishesh Singh, Carolina Zani, Natália Ransolin, and Claudia Guerra Disconzi

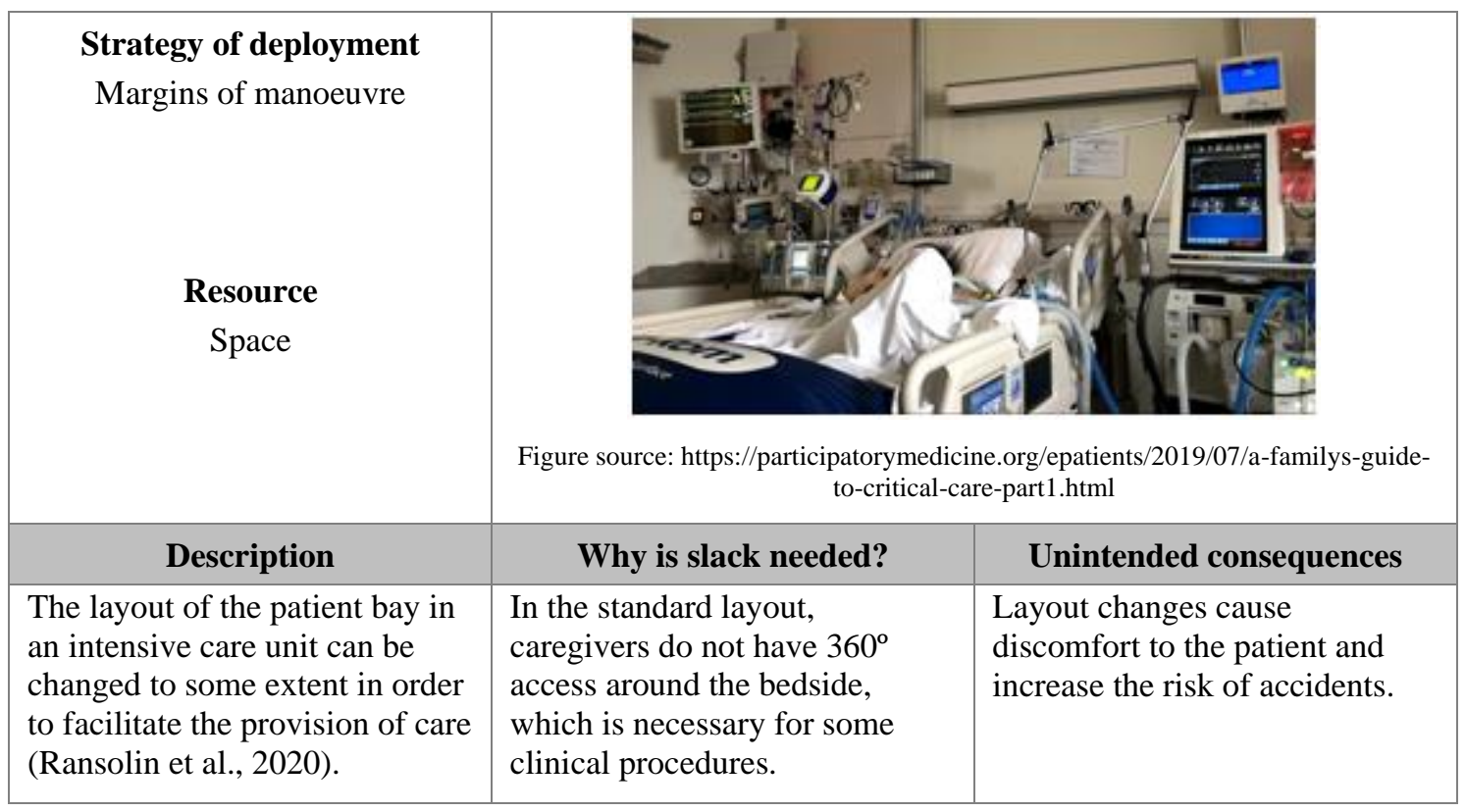

Figure 4: Example 4 - changes in the layout of bays in hospitals as slack

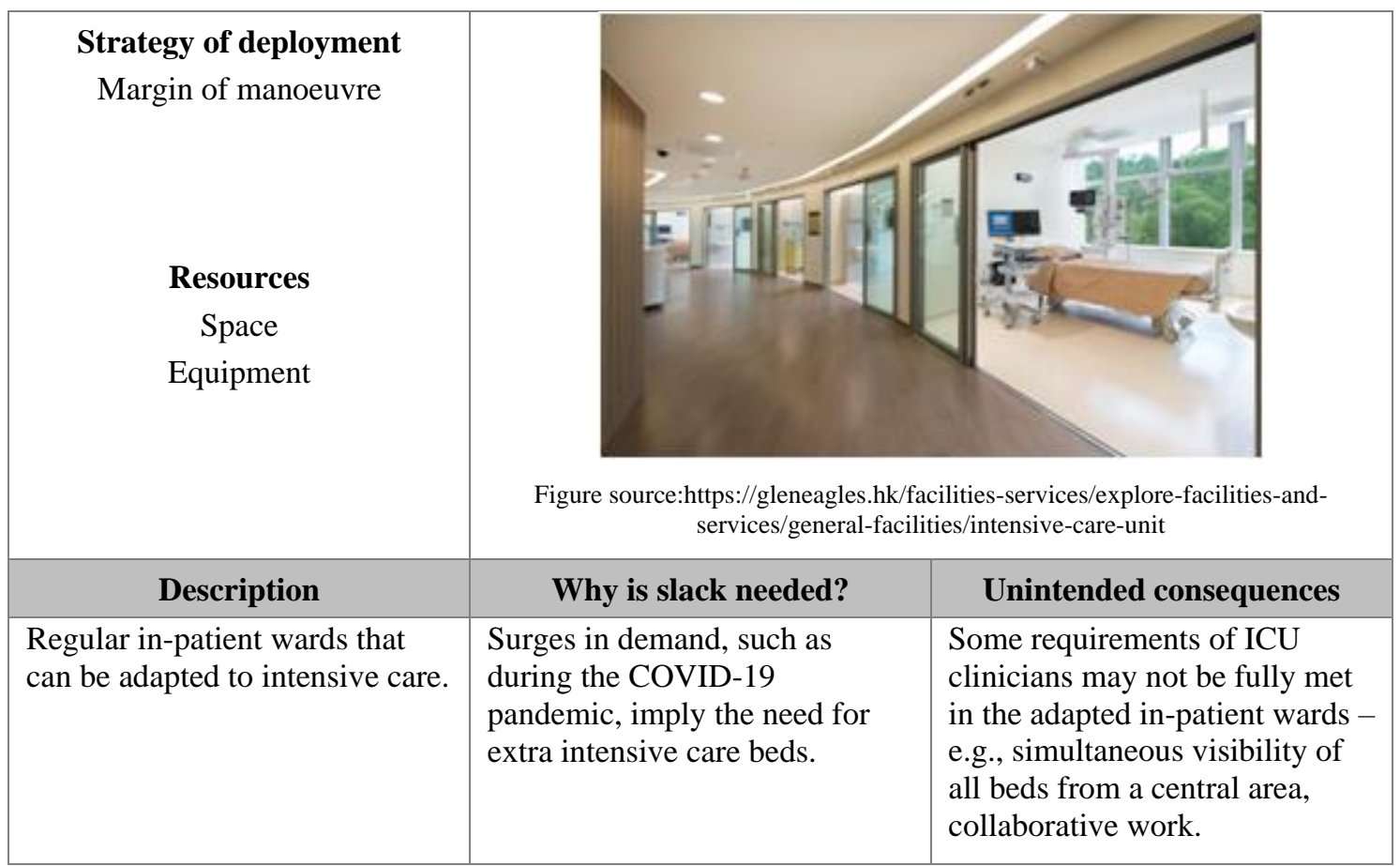

Figure 5: Example 5 - In-patient wards that can be adapted to intensive care (Capolongo et al., 2020). 


\begin{tabular}{|l|l|}
\hline $\begin{array}{l}\text { Strategy of deployment } \\
\text { Redundancy }\end{array}$ \\
$\begin{array}{c}\text { Resource } \\
\text { Space }\end{array}$ \\
$\begin{array}{l}\text { Description } \\
\begin{array}{l}\text { More than one escape route or } \\
\text { emergency exit (e.g., in case of } \\
\text { fire) }\end{array}\end{array} \begin{array}{l}\text { One of the escape routes or exits } \\
\text { may be overcrowded or } \\
\text { temporarily unavailable }\end{array}$ & $\begin{array}{l}\text { Costs with refurbishment and } \\
\text { adaptation of facilities as to } \\
\text { provide alternatives }\end{array}$ \\
\hline
\end{tabular}

Figure 6: Example 6 - alternative escape routes and exits as slack (Kendik, 1986).

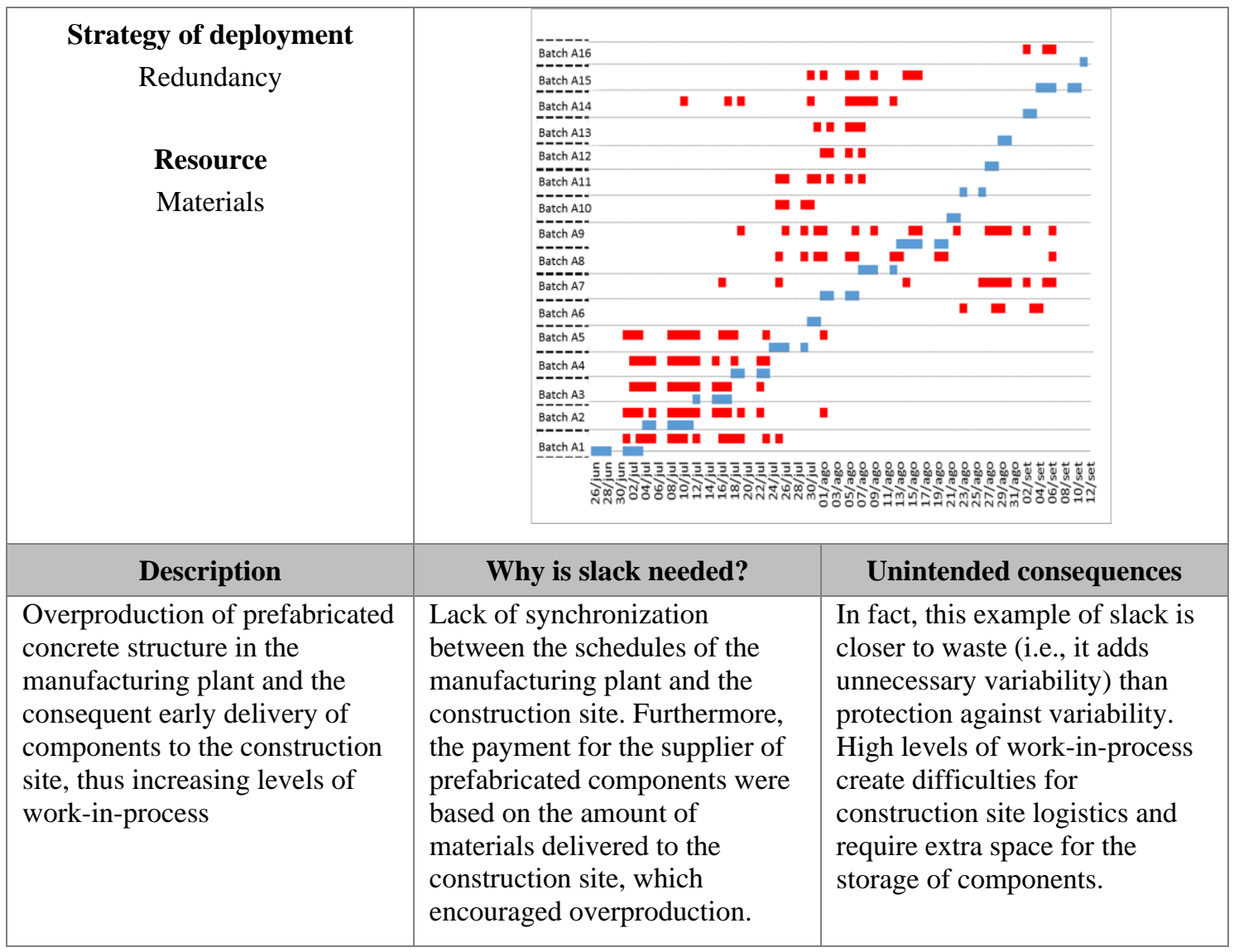

Figure 7: Example 7 - work-in-progress in prefabricated building systems as slack 
Tarcisio Abreu Saurin, Daniela Dietz Viana, Carlos Torres Formoso, Iris D. Tommelein, Lauri Koskela, Marcus Fireman, Karina Barth, Fernanda Bataglin, Rafael Coelho, Vishesh Singh, Carolina Zani, Natália Ransolin, and Claudia Guerra Disconzi

\begin{tabular}{|l|l|l|}
\hline $\begin{array}{c}\text { Strategy of deployment } \\
\text { Margin of manoeuvre }\end{array}$ \\
\multicolumn{1}{|c|}{$\begin{array}{c}\text { Resource } \\
\text { People }\end{array}$} \\
$\begin{array}{l}\text { Description } \\
\text { Construction sites were closed for } \\
\text { several weeks during the most } \\
\text { critical phases of the COVID-19 } \\
\text { pandemic. Technical staff changed } \\
\text { their roles and formed a working } \\
\text { group for reviewing and improving } \\
\text { the company's managerial processes } \\
\text { such as performance measurement } \\
\text { and production planning and } \\
\text { control }\end{array}$
\end{tabular}

Figure 8: Example 8 - Reallocation of staff during the COVID-19 pandemic as slack

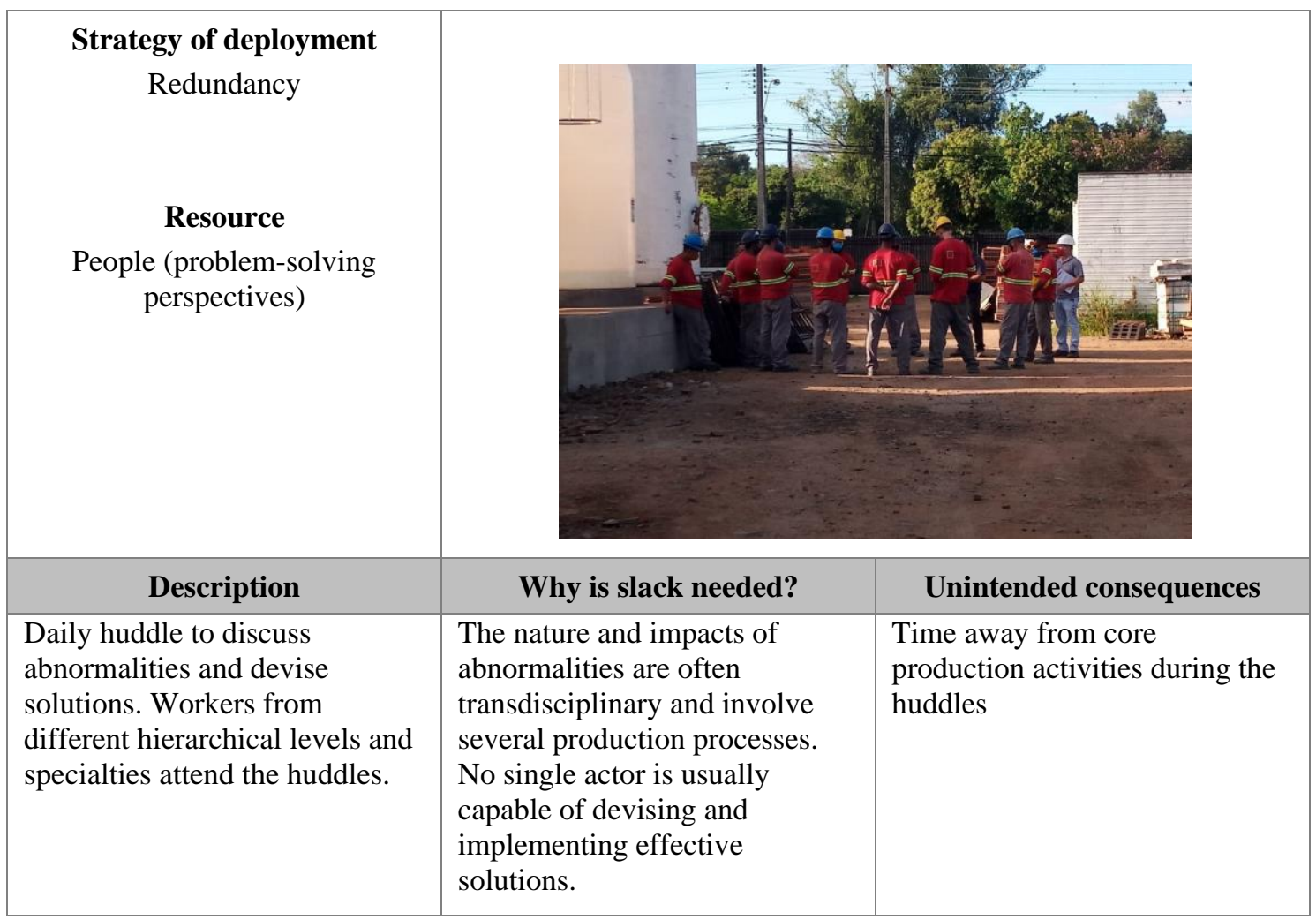

Figure 9: Example 9 - daily huddle to respond to abnormalities as slack 
Both examples that use daily huddles (Figures 1 and 9) emphasize the need to monitor and anticipate the system status. This is an important practice in changing environments, in which unexpected events may emerge.

Four out of the nine examples $(1,3,8,9)$ show how people can be slack resources under different circumstances. In examples 1,3 , and 8 , although workers are reallocated from one task to another, there are implementation differences. In example 1, in which workers are reallocated across gangs and shifts to meet daily production goals, the identification of the need for slack occurs on the spot. Workers are shifted to a task of higher priority as a result of short-term needs. Meanwhile, in example 3, managers were well aware of the risks of having only one crane operator, and therefore they cared for the hiring of a backup crane operator who would be full-time available in the construction site.

The role of the product design process (and of the design itself) for the provision of slack was also highlighted by some examples. In example 2, a set-based design approach produced alternative designs for the foundations of electricity transmission towers - this strategy stems from the experience of the contractor and from the intrinsic uncertainty of soil surveys. In example 6, several escape routes were designed as a result of regulatory requirements. While example 2 consists of multiple redundant designs, example 6 consists of a single design that produces redundant solutions. Examples 2 and 6 also suggest that product design can be a cost-effective means of deploying slack resources e.g., it is very likely cheaper to design alternative foundations than to make changes on the spot to adapt an inadequate design.

As for examples 4 and 5, they both refer to slack in the built environment of healthcare facilities. However, the nature of the slack strategy differs in terms of their designed or opportunistic character. In example 4 (layout of patient bays in an intensive care unit) the burden of adjusting performance lies on the shoulders of front-line caregivers. In example 5 , the flexibility of in-patient wards was devised during the building design stage.

\section{CONCLUSIONS}

This paper presented nine practical examples of slack in the construction industry. The examples suggest that: $(i)$ slack plays a role in a wide range of processes such as contract management, safety management, supply chain management, product design and development, and production planning and control; (ii) slack is deployed through a variety of strategies and resources, which are not limited to the traditional buffer resources of time, inventory, and capacity; (iii) slack has a social-technical nature, which means that people's behaviours and knowledge play a role as slack resources; and (iv) slack is often implicit in existing practices (e.g., daily huddles - example 9), which may reflect its high reliability (e.g., alternative designs for foundations - example 2) or infrequent use (e.g., alternative emergency exists - example 6) - in both cases there is a risk of taking for granted the availability of slack, which can lead to complacency. These characteristics of slack indicate that it has a broader meaning and implications than the concept of buffer. Thus, this article adds empirical evidence to the study by Formoso et al. (2021), which argues for the use of the concept of slack as an alternative to the concept of buffer in lean construction.

Furthermore, our findings suggest that the development of a descriptive and prescriptive theory of slack in construction is a goal worth pursuing as it can unify apparently disparate concepts and practices that share the same underlying fundamental properties and objectives. This theorization might be useful for making it systematic the 
application of slack in construction, giving visibility to its presence (or lack) and offering new tools for project managers.

As a limitation, the examples presented in this paper are short of detailed contextual information, which means that a deeper analysis of how slack interacted with other elements of the construction projects was not undertaken. For the same reason, there was no discussion of how slack evolved over time and how different slack resources could play complementary roles.

Based on the findings of this study and its companion paper, a number of opportunities for future research are proposed:

(i) The investigation of the trade-off between slack and waste, shedding light on the criteria to be accounted for when managing that trade-off;

(ii) The understanding of slack resources at different scales, encompassing the micro (e.g., construction activities), meso (e.g., project management at the site and company level), and macro levels (e.g., supply chain, regulations) of the construction industry;

(iii) The analysis of the implications of slack for innovation and resilience in construction;

(iv) The understanding of slack in a wide variety of management processes. Production planning and control stands out due to its central role in construction management, which makes it potentially useful for the identification of the need for slack (and deployment of slack) in other processes such as procurement, quality and safety management. In addition, the investigation of slack in product development seems to be a promising approach as it has the potential for more cost-effective solutions in comparison to those devised on the spot during the construction stage;

(v) The exploration of the interactions between slack resources and slack strategies, in order to identify synergistic relationships and possible conflicts; and

(vi) Quantitative investigations of the impact of slack on the performance of construction projects, comparing projects with different levels and types of slack.

\section{ACKNOWLEDGMENTS}

This research was supported in part by the Project Production Systems Laboratory (P2SL) at UC Berkeley. Any opinions, findings, conclusions, or recommendations expressed in this paper are those of the authors and do not necessarily reflect the views of P2SL or its members.

\section{REFERENCES}

Ashby, W.R. (1991). "Requisite variety and its implications for the control of complex systems.” In: Facets of systems science, pp. 405-417. Springer, Boston, MA.

Azadeh, A., Kolaee, M.H., and Salehi, V. (2016). "The impact of redundancy on resilience engineering in a petrochemical plant by data envelopment analysis." Proc. Inst. of Mech. Engineers, Part O: J Risk and Reliability, 230(3): 285-296.

Bourgeois, J. (1981). "On the measurement of organizational slack." Academy Management Review, 6(1): 29-39.

Capolongo, S., Gola, M., Brambilla, A., Morganti, A., Mosca, E. I., and Barach, P. (2020). "COVID-19 and Healthcare Facilities: a Decalogue of Design Strategies for Resilient Hospitals." Acta Biomed., Vol. 91, Suppl. 9:50-60. doi.org/10.23750/abm.v91i9$\underline{\text { S.10117. }}$.

Gerwin, D. (1993). "Manufacturing flexibility: a strategic perspective." Management Science, 39:395-410. 
Fireman, M.C.T and Saurin, T.A. (2020). "Chain of Wastes: The Moderating Role of Making-do." In: Tommelein, I.D. and Daniel, E. (eds.). Proc. $28^{\text {th }}$ Ann. Conf. Int. Group for Lean Constr. (IGLC28), Berkeley, CA, USA, pp. 409-420.

Formoso, C.T., Tommelein, I.D., Saurin, T.A., Koskela, L., Fireman, M.C.T, Barth, K., Bataglin, F., Viana, D.D, Coelho, R.V., Singh,V., Zani, C., Ransolin, N., and Disconzi, C. (2021). "Slack in Construction - Part 1: Core Concepts." In: Alarcon, L.F. and González, V.A. (eds.). Proc. $29^{\text {th }}$ Ann. Conf. Int. Group for Lean Constr. (IGLC29), Lima, Peru. In Press.

Hollnagel, E. (2012). FRAM: The Functional Resonance Analysis Method-modeling complex socio-technical systems. Burlington: Ashgate.

Kendik, E. (1986). "Designing escape routes in buildings." Fire Techn., 22(4), 272-294.

Koskela, L. (2000). An exploration towards a production theory and its application to construction. Thesis (Doctor of Technology), Tech. Res. Centre of Finland (VTT), Helsinki, Finland, 296 p.

Nonaka, I. (1990). "Redundant, Overlapping Organizations: A Japanese approach to managing the innovation process." Calif. Manage. Rev., 32, 3, 27-38.

Ransolin, N., Saurin, T.A., and Formoso, C.T. (2020). "Integrated modelling of built environment and functional requirements: implications for resilience." Applied Ergonomics, 88, 103154.

Saurin, T.A. and Werle, N.B. (2017). "A framework for the analysis of slack in sociotechnical systems." Reliability Engineering and Systems Safety, 167, 439-451.

Spearman, M.L. and Hopp, W.J. (2020). "The case for a unified science of operations". Prod. and Operations Manage, In Press, doi.org/10.1111/poms.13318. 